\title{
THE PETROLOGY AND MINERALOGY OF PERIDOTITE XENOLITHS FROM THE BULTFONTEIN, WESSELTON, DUTOITSPAN AND ROBERTS VICTOR KIMBERLITES
}

\author{
G.G. Whitfield, \\ P.O. Box 106, \\ Kenhardt. Cape. R.S.A.
}

Forty-two well-rounded peridotite xenoliths, found in the abovementioned kimberlite diatremes, have been studied by conventional petrological and mineralogical techniques. Quantitative data is presented and their origin and occurrence in kimberlite explained.

Petrographically the xenoliths can be divided into three main groups, namely, garnet peridotite (twenty-four xenoliths comprising sixteen iherzolites and eight harzburgites), spinel peridotite (eleven xenoliths comprising six lherzolites and five harzburgites) and highly altered or granulated peridotite of essentially dunitic composition (seven xenoliths). Macroscopically and in thin section the garnet and spinel. peridotites are virtually identical, both being relatively fresh, phanerocrystalline, medium to coarse-grained, allotriomorphic aggregates of olivine and orthopyroxene with possible minor or trace amounts of wine-red garnet, bright green clinopyroxene, phlogopite, black chrome spinel, and rarely traces of graphite and sulphides. Several specimens contain both garnet and spinel, with one phase present in a trace amount. Most of the xenoliths display microscopic features consistent with a notable degree of tectonic deformation, and in cases, recrystallisation, clearly indicating that at some stage, before incorporation into the kimberlite magma, the peridotites were tectonically disturbed.

The average modal composition of the garnet peridotites is $65 \%$ olivine, $29 \%$ orthopyroxene, $0,7 \%$ clinopyroxene, $4,6 \%$ garnet and 1,0\% phlogopite while the garnet peridotite xenoliths most closely approaching suggested compositions of the upper mantle consists of $65 \%$ olivine, $22 \%$ orthopyroxene, 5, $0 \%$ clinopyroxene, 5,9\% garnet and 1,2\% phlogopite. The average modal composition of the spinel peridotites is $72 \%$ olivine, $25 \%$ orthopyroxene, $0,1 \%$ clinopyroxene, $0,4 \%$ spinel and $2,2 \%$ phlogopite.

Chemical analyses of nine garnet peridotites and four spinel peridotites reveal that the specimens are more or less identical, all being undersaturated, olivine-normative rocks of tholeiitic character and typical ultrabasic composition. No significant variations are apparent and the small differences can be explained by variations in the modal composition.

The olivine composition, determined by $\mathrm{X}$-ray and optical methods, ranges from Fo91 to Fo94, and is confirmed by chemical analyses of five pure separates; nickel is always present in a minor amount. The olivine shows some serpentinisation and normally displays uneven optical extinction, deformation lamellae and marginal granulation or distinct recrystallisation, indicating intensive tectonic deformation. 
Orthopyroxene compositions, estimated from optical properties, range from En88 to En91, and are supported by chemical analyses of five pure separates. The orthopyroxene from the garnet peridotites are deficient in aluminium and calcium compared with that from spinel peridotite, indicating formation under higher pressure conditions. Chrome is an important minor constituent. In thin section uneven optical extinction is typical and kink bands and bent crystals are common, similarly indicating testonic deformation.

The bright green clinopyroxene (chrome diopside) has not been studied in detail but a chemical analysis of one pure separate shows it to consist mainly of diopside with appreciable amounts of enstatite and jadeite in solid solution. From chemical calculations it is estimated that the analysed chrome diopside formed at a depth of 125 kilometres.

The vividly coloured garnets fall into a small compositional range rich in the pyrope end-member but also containing almandine, andradite, uvarovite, plus minor grossularite and spessartite. The average three end-member garnet composition, estimated from refractive index and unit cell size is 73\% pyrope, $14 \%$ almandine and $13 \%$ andradite/uvarovite. Partial chemical analyses of four pure separates indicate the essential reliability of the estimated compositions. The garnets are typical of those found in kimberlites and orogenic dunites and serpentinites; their pyrope-rich composition points to formation at very high pressures.

Phlogopite is, in certain cases, undoubtedly of primary origin, especially so when exhibiting gross deformation structures. The presence of a primary potassium and waterbearing phase, also capable of providing radiogenic heat, in rocks of probable upper mantle origin is of considerable petrogenic significance.

Basically three main theories have been used to account for the peridotite xenoliths in kimberlite; these are firstly as accidentally included fragments of high-grade crustal peridotite; secondly as a segregated or accumulated co-magmatic phase of the kimberlite; thirdly as fragments of upper mantle material. This study shows that texturally, mineralogically and chemically the peridotites are remarkable similar. Variations in both the mineral assemblage and individual mineral compositions can be explained by formation under varying temperature/pressure conditions and by a process of partial melting and depletion in certain constituents. A comparison of peridotite xenoliths from other kimberlites, on a world-wide scale, likewise reveals their essential similarity to those described above. It must be concluded that all such xenoliths are derived from one source of relatively constant mineralogical and chemical composition, and of universal extent. Present day thinking points to an upper mantle of peridotitic composition as being the most likely source.

The following major conclusions are made:- 1. The xenoliths represent upper mantle material carried to near surface by a volatile-rich, rapid moving kimberlite magma originating from depths of at least 125 kilometres. 2. The xenoliths do not represent primary upper mantle material but 
rather portions which have undergone significant tectonic activity and varying degrees of partial melting with resultant depletion of the more easily fused constituents such as garnet, chrome diopside and phlogopite. The completely recrystallised dunitic xenoliths possibly represent the end product of this trend. 3. The spinel peridotites differ from the garnet peridotites in that they formed at a shallower depth in the upper mantle and generally show slightly more partial melting. A minor transitional zone probably exists between the two groups. 4. Evidence indicates that the xenoliths are not cognate with the kimberlite. It is highly unlikely that kimberlite magmas of variable composition could produce, by any process, a suite of such uniform and wide-spread rocks. 5. Kimberlites are generated within the garnet peridotite (phlogopite-bearing?) of the upper mantle and much of the fragmentary material in kimberlite is probably derived from comminution of incorporated peridotite. No diamonds however have ever been found in true peridotite xenoliths. 